\title{
Confidence of UK Ophthalmology Registrars in Managing Posterior Capsular Rupture: Results from a National Trainee Survey
}

\author{
Andrew J. Swampillai - Victoria A. Nowak - Laura Maubon · \\ James E. Neffendorf · Dilraj Sahota · Olayinka Williams · \\ Bansri Lakhani $\cdot$ Cristina Soare $\cdot$ Ivan Sychev $\cdot$ Edward Ridyard · \\ Praveen J. Patel · Jonathan C. Park
}

Received: September 2, 2021 / Accepted: November 1, 2021 / Published online: November 19, 2021

(C) The Author(s) 2021

\section{ABSTRACT}

Introduction: To establish the level of confidence amongst UK ophthalmology specialist registrars (residents) in managing posterior capsule rupture (PCR) during cataract surgery.

Methods: An online nine-item questionnaire was distributed to all registrars, recruited nationwide via regional representatives. Data collected included stage of training, number of completed cataract operations, cumulative PCR rate, number of PCRs independently managed, understanding of vitrectomy settings and fluidic parameters and access to simulation.

Victoria A. Nowak and Laura Maubon are joint second authors.

A. J. Swampillai · J. C. Park (ه)

Department of Ophthalmology, Musgrove Park

Hospital, Parkfield Drive, Taunton TA1 5DA,

Somerset, UK

e-mail: Jonathan.Park@SomersetFT.nhs.uk

V. A. Nowak

Royal Free London Hospital, London, UK

L. Maubon · C. Soare

St. Thomas' Hospital, London, UK

J. E. Neffendorf

Oxford Eye Hospital, Oxford University Hospitals,

Oxford, UK

D. Sahota

Queen Elizabeth Hospital, Birmingham, UK
Respondents self-evaluated their confidence in managing PCR with vitreous loss.

Results: Complete responses were obtained from 248 registrars (35\% response rate). Mean number of phacoemulsification procedures performed was 386. For senior registrars (OST 6-7), 35 out of 70 (50\%) felt confident to manage PCR independently and 55 out of 70 $(78.6 \%)$ were either quite confident or very confident at deciding when to implant an intraocular lens during PCR management. Lower confidence levels were noted for junior trainees (OST 1-2). Over 65\% of survey respondents had access to relevant simulation.

Conclusions: Our results represent the largest UK survey analysing the confidence of PCR management amongst registrars. Confidence improves with duration of training and

O. Williams

Gartnavel General Hospital, Glasgow, Scotland, UK

B. Lakhani

Queen's Medical Centre, Nottingham, UK

I. Sychev

Manchester Eye Hospital, Manchester, UK

E. Ridyard

St. James's University Hospital, Leeds, UK

P. J. Patel

NIHR Biomedical Research Centre at Moorfields Eye Hospital NHS Foundation Trust and UCL Institute of Ophthalmology, London, UK 
increased exposure to management of PCR. However, $50 \%$ of senior registrars still lacked confidence to independently manage PCR and vitreous loss. A specific competency-based framework, potentially using a simulator or simulating a PCR event, incorporated into the curriculum may be desirable.

Keywords: Cataract surgery; Complications; Phacoemulsification; Simulation; Training; Vitrectomy; Vitreous loss

\section{Key Summary Points}

Why carry out this study?

Posterior capsule rupture (PCR) is a relatively rare event and is considered the benchmark complication for considering the safety of cataract surgery.

PCR rate is higher for trainees relative to consultants or associate specialists.

This survey aimed to ascertain the confidence of UK ophthalmic specialist trainees (OST), at different stages of residency, in managing this complication.

\section{What was learned from the study?}

Knowledge of the theoretical principles and understanding of fluidics were significantly lacking in OST years 4 and below and were not unanimous amongst more senior trainees in years 6-7.

The perceived accessibility of anterior vitrectomy simulation varies across the regions. To improve trainee competency in managing PCR, the study group suggests targeted training and simulation.

\section{INTRODUCTION}

Phacoemulsification for cataract surgery is the most commonly performed surgical procedure in the National Health Service (NHS), with approximately 350,000 operations per year [1]. It is estimated that over $30 \%$ of persons in the United Kingdom (UK), aged 65 years and over, will have visually significant cataracts in one or both eyes [2].

Posterior capsule rupture (PCR) is widely regarded as the benchmark complication to judge surgical quality of cataract surgery [3]. Following PCR, there is a significantly increased risk of endophthalmitis (8-fold), retinal detachment (42-fold) and of visual loss (5.6fold) [4]. In a study by Ti et al. cases complicated by PCR and dropped nucleus had significantly worse visual outcomes than those complicated by PCR alone $(83.1 \%$ vs $94.8 \%$ achieving BCVA $20 / 40 ; P<0.001$ ) [5]. One of the most significant risk factors for PCR is surgeon experience, with junior registrars (residents) having an adjusted odds ratio of 3.73 in comparison to consultants [6]. It is therefore important for all ophthalmic surgeons in training to become proficient in the overall management of PCR (with or without vitreous loss) to optimise patient outcomes.

Ophthalmic specialist training (OST) in the UK is 7 years in duration and registrars must complete a minimum of 350 phacoemulsification cases in order to be eligible for 'Certification of Completion of Training' (CCT) [7]. Until recently, cataract surgical training in the UK was largely experiential in nature, whereby the registrar performed steps of phacoemulsification through a sequence of observation and hands-on experience. While PCR occurrence is relatively common in the early stages of training, opportunities for registrars to gain handson experience are variable, often with the supervising surgeon taking over. Although the risk of intraoperative complications reduces as a registrar progresses in training [8], it has been suspected that experience with independently managing PCR is still limited by the end of OST. Turnbull and Lash conducted a regional survey in 2016, where only $18.2 \%$ of registrars felt confident in managing PCR and vitreous loss without senior support [9]. We designed a survey to investigate this question on a nationwide level and assess the subjective confidence of UK registrars in managing $\mathrm{PCR}$, with reference to their stage of training and surgical experience. 


\section{METHODS}

A nine-stem anonymous questionnaire (Table 1) was distributed via an online webbased platform (SurveyMonkey, San Mateo, California, USA) to all UK registrars in years 1-7. Prior to survey distribution, a Health Research Authority decision tool deemed ethical approval was not required [10]. The survey was distributed via survey leads appointed by the South West Ophthalmic Research Matrix and the London Ophthalmology Clinical Trial Network, using methodology developed from a registrar-led clinician practice survey [11]. Survey leads ensured regional dissemination using a combination of electronic communication. Reminders were sent through regional training programme directors.

This article does not contain any new studies with human or animal subjects performed by any of the authors.

The survey was voluntary and only one response per registrar was permitted. Registrars who had not completed at least five phacoemulsification procedures were excluded from the final analysis. The SurveyMonkey online calculator algorithm estimated the minimum required sample size from a total population of 706 registrars at the time (with a confidence level of $95 \%$ and a margin error of $10 \%$ ) to be 85 . Statistical analysis was performed with Statistical Package for Social Sciences (SPSS) version 26 (IBM SPSS Statistics Inc., Chicago, IL, USA). For the purposes of this survey, junior grade registrars were defined to be OST $1-2$, middle grade registrars at OST $3-5$ and senior grade registrars at OST 6-7. Histogram plots were used to determine normality of the data. The Spearman's rank correlation coefficient test was used to assess for any relation between the numbers of phacoemulsification procedures performed and numbers of PCR cases managed.

\section{RESULTS}

A total of 250 responses were initially received, of which two responses were excluded. Therefore 248 completed surveys responses were analysed; 247 (99.6\%) were completed by registrars in General Medical Council accredited training programmes and one response in a Locum Appointment for Training (LAT) post. The survey accumulated the views of approximately $35 \%$ of OST population in the UK at the time of running. Responses were received from all training deaneries. The responses captured a relatively variable spread amongst training years $1-7$, the highest response rates being from those in year 4 and 5 of OST (Fig. 1).

The mean and median number of phacoemulsification procedures achieved was higher than the minimum numbers requirement for CCT from years 5 to 7 (Table 2). Two OST 7 registrars had less than the required number of phacoemulsification procedures for CCT at the point of data entry. The lowest numbers were seen at OST 1 (6 cases) and the highest at OST 7 (1602 cases).

By year 4 most responders had some experience managing PCR and by year 7 the median was 4 cases (Table 2). The registrar who managed a single PCR had the lowest phacoemulsification procedures of 6 at OST 1 level. The registrar with the highest number of phacoemulsification procedures (1602) had managed 5 PCR cases at OST 7 level. The most number of PCRs managed (20 cases) was by a registrar at OST 7 level with 1400 phacoemulsification procedures. The data was found to be non-normally distributed. A moderately positive correlation was observed that as registrars performed more phacoemulsification procedures, more experience in PCR management was gained by the number of cases they managed with this complication $(r=0.736$, $p=<0.01)$.

\section{Theoretical Principles of Managing PCR and Vitreous Loss}

Figure 2 shows the survey results of trainee confidence in their understanding of the theoretical principles of PCR management. Up to $47.6 \%$ of registrars surveyed across all training years reported that they understood the theory behind management but would only attempt this with senior support. Only $31.1 \%$ felt 
Table 1 Survey summary (as used in the SurveyMonkey online version)

\begin{tabular}{|c|c|c|c|c|}
\hline & Answer & & & \\
\hline $\begin{array}{l}\text { What is your current year } \\
\text { of training? }\end{array}$ & Free text & & & \\
\hline $\begin{array}{l}\text { What deanery are you } \\
\text { presently training in? }\end{array}$ & Free text & & & \\
\hline $\begin{array}{l}\text { How many cataract } \\
\text { surgeries have you } \\
\text { completed in total? }\end{array}$ & Free text & & & \\
\hline $\begin{array}{l}\text { How many cases of PCR } \\
\text { have you personally } \\
\text { managed (with or } \\
\text { without supervision)? }\end{array}$ & Free text & & & \\
\hline $\begin{array}{l}\text { How confident are you } \\
\text { with understanding the } \\
\text { theoretical principles of } \\
\text { managing PCR and } \\
\text { vitreous loss? }\end{array}$ & $\begin{array}{l}\text { Not confident as } \\
\text { my } \\
\text { understanding } \\
\text { is limited }\end{array}$ & $\begin{array}{l}\text { Understand the } \\
\text { theoretical principles } \\
\text { but not confident } \\
\text { enough to attempt } \\
\text { management under } \\
\text { supervision/on my own }\end{array}$ & $\begin{array}{l}\text { Understand the } \\
\text { theoretical } \\
\text { principles and } \\
\text { would attempt } \\
\text { management but } \\
\text { only under } \\
\text { supervision }\end{array}$ & $\begin{array}{l}\text { Understand the } \\
\text { theoretical } \\
\text { principles and } \\
\text { confident to } \\
\text { manage PCR and } \\
\text { vitreous loss by } \\
\text { myself }\end{array}$ \\
\hline $\begin{array}{l}\text { With PCR and vitreous } \\
\text { loss, how confident do } \\
\text { you feel with deciding } \\
\text { what vitrectomy settings } \\
\text { and fluidic parameters } \\
\text { are required? }\end{array}$ & $\begin{array}{l}\text { Not confident at } \\
\text { all }\end{array}$ & $\begin{array}{l}\text { Not particularly } \\
\text { confident-would } \\
\text { require senior support }\end{array}$ & $\begin{array}{l}\text { Quite confident-can } \\
\text { manage with } \\
\text { minimal senior } \\
\text { input }\end{array}$ & Very confident \\
\hline $\begin{array}{l}\text { With PCR and vitreous } \\
\text { loss, how confident do } \\
\text { you feel with deciding } \\
\text { when, where and how to } \\
\text { implant an intraocular } \\
\text { lens? }\end{array}$ & $\begin{array}{l}\text { Not confident at } \\
\text { all }\end{array}$ & $\begin{array}{l}\text { Not particularly } \\
\text { confident-would } \\
\text { require senior support }\end{array}$ & $\begin{array}{l}\text { Quite confident-can } \\
\text { manage with } \\
\text { minimal senior } \\
\text { input }\end{array}$ & Very confident \\
\hline $\begin{array}{l}\text { Overall, how confident do } \\
\text { you feel in managing } \\
\text { PCR with vitreous loss? }\end{array}$ & $\begin{array}{l}\text { Not confident at } \\
\quad \text { all }\end{array}$ & $\begin{array}{l}\text { Not particularly } \\
\text { confident-would } \\
\text { require senior support }\end{array}$ & $\begin{array}{l}\text { Quite confident_can } \\
\text { manage with } \\
\text { minimal senior } \\
\text { input }\end{array}$ & Very confident \\
\hline
\end{tabular}


Table 1 continued

\begin{tabular}{ll}
\hline \multicolumn{1}{c}{ Answer } & No \\
\hline Do you have access to any Yes & \\
simulated training for & \\
performing anterior & \\
vitrectomy (either in \\
your hospital or \\
deanery)?
\end{tabular}

60

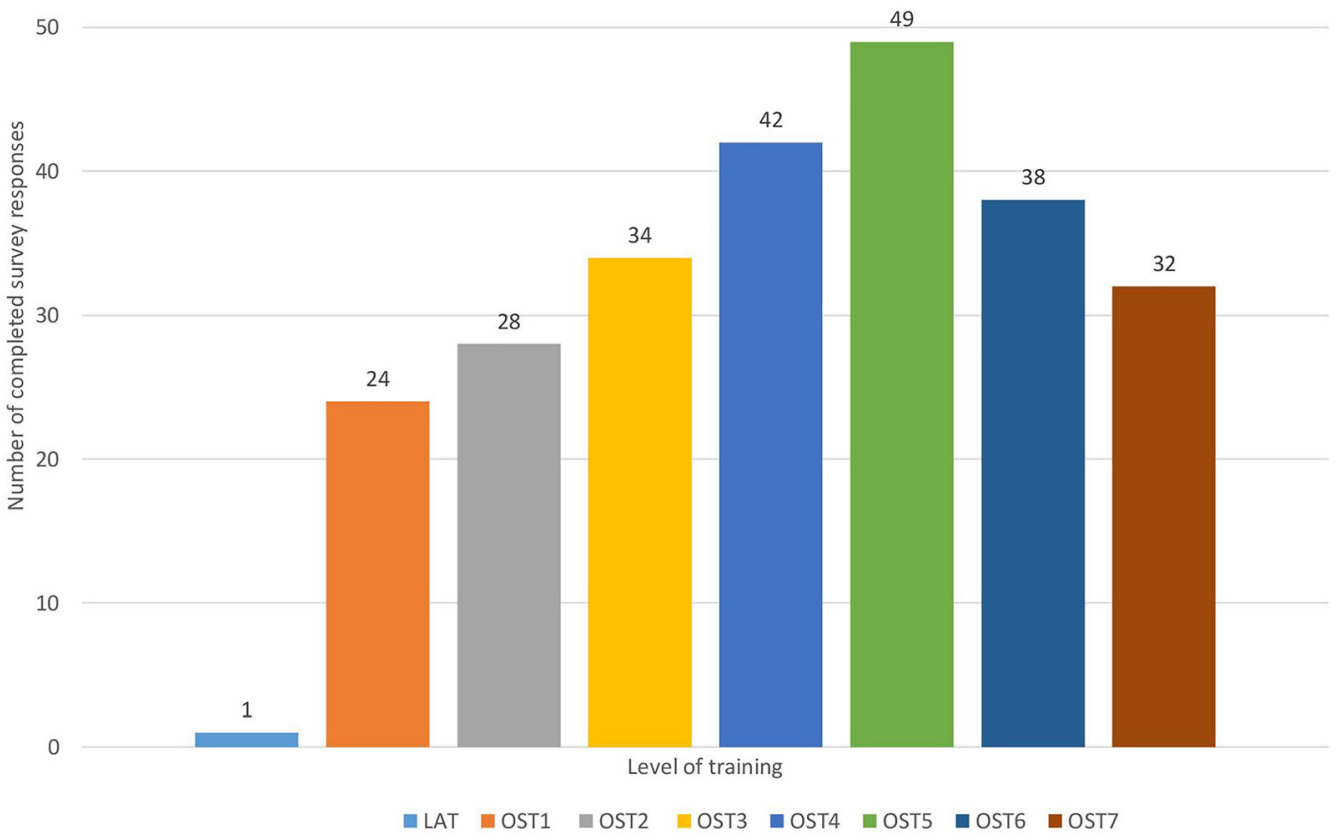

Fig. 1 Completed survey responses by individual OST training level

subjectively comfortable with performing this independently.

Subgroup analysis revealed $64.8 \%$ of registrars at OST 3-5 level (81 out of 125) understanding theory and attempting management under supervision. At OST 6-7 level, 72.8\% (51 out of 70) subjectively felt able to understand theoretical aspects and attempt management independently.

\section{Deciding Anterior Vitrectomy Settings and Fluidic Parameters Required}

Despite a perceived confidence amongst more experienced registrars in theoretical understanding of PCR and vitreous loss, far less confidence was expressed overall across training years for deciding anterior vitrectomy settings and fluidic parameters (Fig. 3). Of all survey 
Table 2 Mean number of independent phacoemulsification procedures performed and posterior capsular ruptures (PCR) managed as the registrar operating with or without assistance per training year

\begin{tabular}{lllllllll}
\hline Year & Survey respondents & $\begin{array}{l}\text { Mean } \\
\text { number of } \\
\text { procedures }\end{array}$ & $\begin{array}{l}\text { Median } \\
\text { number of } \\
\text { procedures }\end{array}$ & $\begin{array}{l}\text { Range of } \\
\text { procedures }\end{array}$ & $\begin{array}{l}\text { Total } \\
\text { number of } \\
\text { PCR } \\
\text { recorded }\end{array}$ & $\begin{array}{l}\text { Mean } \\
\text { number } \\
\text { PCR } \\
\text { managed }\end{array}$ & $\begin{array}{l}\text { Median } \\
\text { number of } \\
\text { PCR } \\
\text { managed }\end{array}$ & $\begin{array}{l}\text { Range of } \\
\text { PCR } \\
\text { managed }\end{array}$ \\
\hline OST1 & 25 & 45 & 30 & $6-208$ & 1 & 0 & 0 & $0-1$ \\
OST2 & 28 & 140.5 & 140 & $42-225$ & 2 & 0 & 0 & $0-1$ \\
OST3 34 & 257 & 250 & $64-551$ & 41 & 1 & 0 & $0-5$ \\
OST4 & 42 & 322 & 331 & $146-450$ & 54 & 1 & 1 & $0-5$ \\
OST5 49 & 454.3 & 430 & $200-800$ & 116 & 2 & 2 & $0-15$ \\
OST6 38 & 595.7 & 517 & $350-1298$ & 120 & 3 & 2 & $0-13$ \\
OST7 32 & 724.7 & 654 & $300-1602$ & 152 & 5 & 4 & $0-20$ \\
\hline
\end{tabular}

responders, $7.3 \%$ rated themselves as very confident, followed by $36.3 \%$ as confident enough to require minimal senior input and $34.3 \%$ as not confident and requiring senior assistance. Subgroup analysis showed that only 18 out of 70 registrars $(25.7 \%)$ at OST $6-7$ level would regard themselves as very confident in this regard. Around $61.4 \%$ (43 out of 70 ) of registrars at the same level felt confident with minimal senior input. Registrars at OST 3-5 level were found to the most likely to place themselves into the category of subjectively not feeling confident and requiring senior support (61 out of 125).

\section{Confidence in Deciding When, Where and How to Implant an Intraocular Lens (IOL) in PCR and Vitreous Loss}

Registrars were assessed in their how they subjectively rated their surgical skills in implanting an IOL in the sulcus with capsular support or deciding to leave an eye aphakic for IOL implantation as a secondary procedure (Fig. 4). Across all training grades, the majority of survey responders rated themselves as not confident and requiring senior support $(43.6 \%)$. For registrars at OST 6-7 level, 55 out of $70(78.6 \%)$ were either quite "confident" or "very confident" at deciding when to implant an IOL during PCR management. Out of the 125 registrars at OST 3-5 level, 66 were not very confident $(48.8 \%)$ while 55 rated themselves confident (44\%).

\section{Overall Confidence of Registrars in Managing PCR with Vitreous Loss}

Table 3 shows the overall confidence for each OST level in managing PCR with vitreous loss and how readily registrars would seek senior input if required to do so. Over 50\% (35 out of 70) of registrars at OST 6-7 level were confident to manage PCR without senior support. At OST 3-5 level, $38.4 \%$ (48 out of 125 ) required senior assistance on stand-by and 41\% (52 out of 125) required senior assistance at the microscope. The majority at OST 1-2 level (67.9\%) would need a supervisor to take over.

\section{Access to Relevant Simulation}

A total of $65 \%$ of responders reported having access to some form of simulation relevant to anterior vitrectomy in their deanery. 


\section{How confident are you with understanding the theorectical principles of managing PCR and vitreous loss}

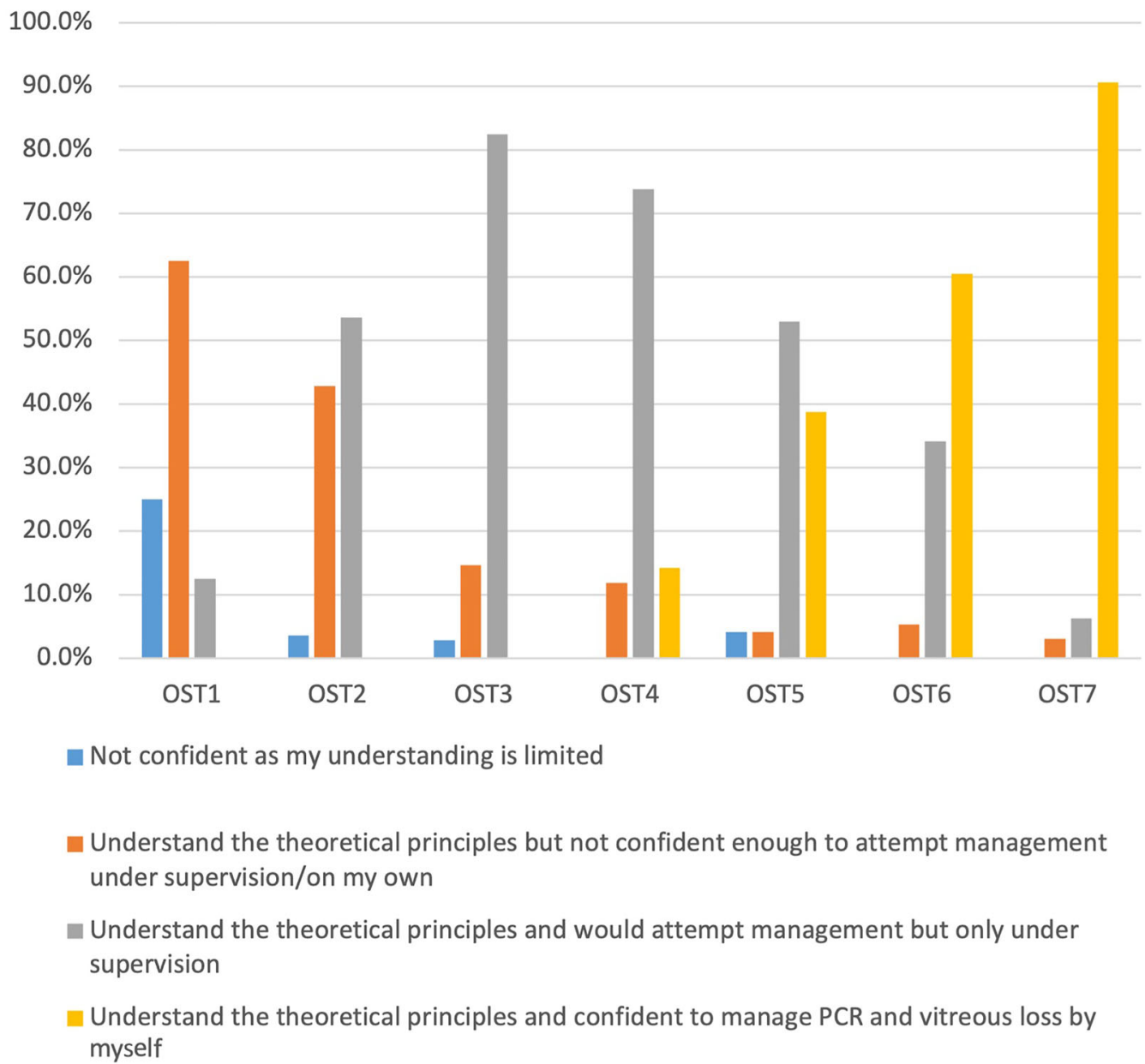

Fig. 2 Confidence of registrars in understanding the theoretical principles of managing PCR and vitreous loss

\section{DISCUSSION}

This is the first national training survey to be circulated through UK ophthalmology trainee research network collaborations. It has a higher response rate in comparison to one conducted in the USA (4.4\%) [12] whilst being comparable to a Canadian survey (40\%) [13]. Although our survey has a lower response rate in comparison to a recent sub-Saharan African study (52\%), the latter comprised 124 responders [14]. The only other UK-based surveys are either regional [9] or have generically inquired on this issue with a lower response rate nationally [15].

Early introduction to phacoemulsification training has been shown to generally reduce intraoperative complications in registrar-performed operations [16]. Phacoemulsification training occurs from OST 1 and a minimum of 50 completed cases are expected to be achieved by the end of OST 2 . It is generally accepted that repeated and deliberate practice (with regular reinforcement) is required to develop surgical expertise [17]. Concerns have been expressed about the impact of the European Working 


\section{With PCR and vitreous loss, how confident do you feel with deciding what vitrectomy settings and fluidic parameters are required?}

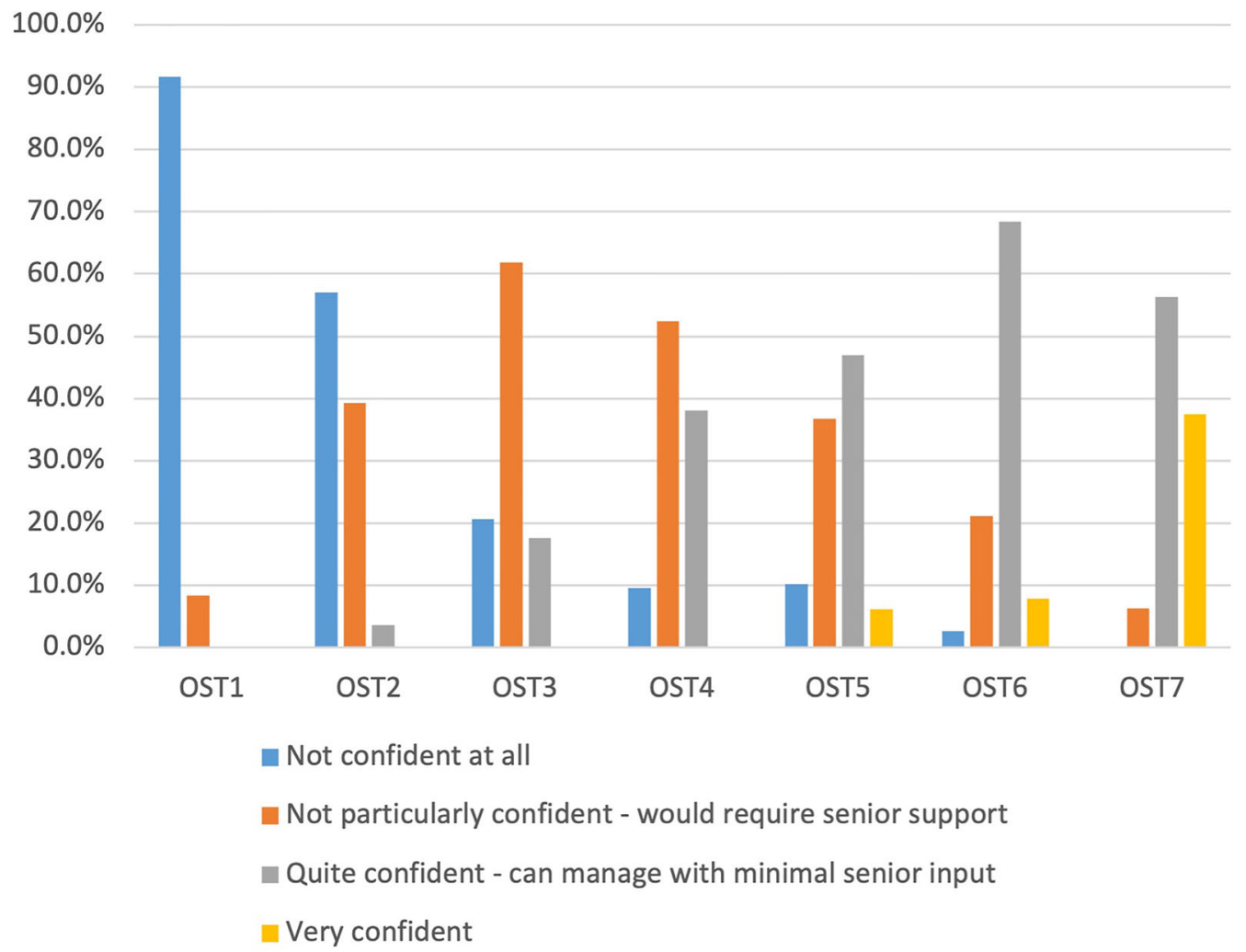

Fig. 3 Confidence of registrars in deciding anterior vitrectomy settings and fluidic parameters required

Time Directive leading to reduced working hours for surgeons, along with the emergence of 'Independent Surgical Treatment Centres' $[18,19]$. These high volume cataract surgery centres usually target less complex cases. Surgically challenging cases carrying a higher risk of PCR, with or without vitreous loss, are inevitably reserved for senior surgeons in an NHS setting. These factors have detrimental consequences for surgical training, with reduced registrar exposure and confidence levels in performing more complex cataract surgery [20]. While it has been suggested that immediate management by vitreoretinal specialists optimises outcomes in cases complicated by PCR [21], this is both impractical from a logistical perspective and fails to take into account that not all ophthalmology departments have an on- site vitreoretinal service. Jamison et al. assessed the real-term costs of PCR to NHS ophthalmology departments (in terms of additional surgical equipment utilised and outpatient visits) and estimated this to be between $£ 1178.20$ and $£ 2124.67$ [22]. An additional concern is the medicolegal aspect, with surgical negligence (including PCR and dropped nucleus) being the most frequent cause for litigation claims involving complicated cataract surgery [23].

In our survey, only 44 out of 161 registrars at OST 4-7 (21.1\%) reported being confident in managing PCR with vitreous loss, without senior support (Table 3). This is lower than reported in another recent UK survey, which found $74.4 \%$ of registrars at the same levels felt subjectively confident in anterior vitrectomy [13]. One reason for this disparity is due to our 


\section{With PCR and vitreous loss, how confident do you feel with deciding when, where and how to implant an intraocular lens?}

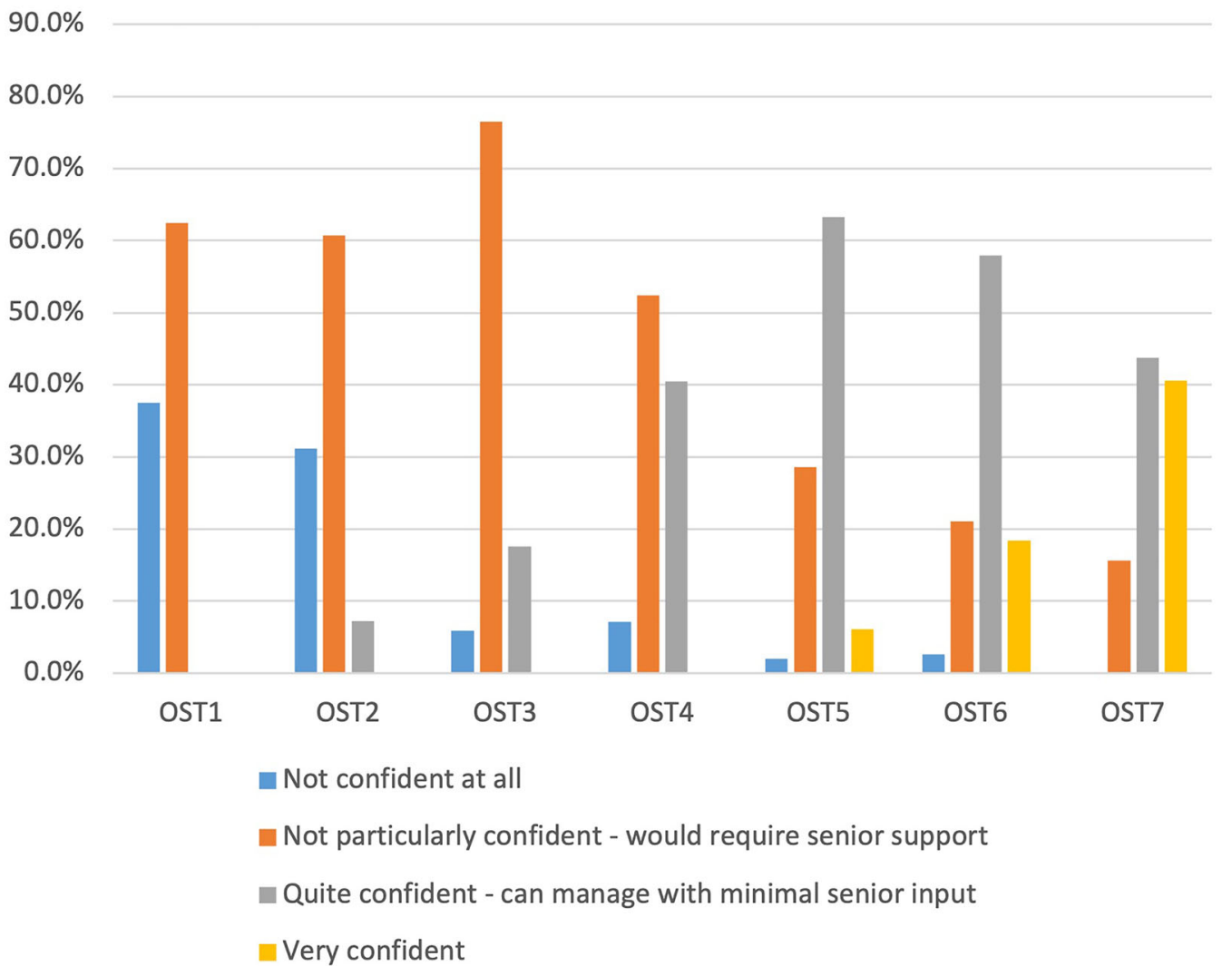

Fig. 4 Confidence of registrars in deciding when, where and how to implant an intraocular lens with vitreous loss

Table 3 Individual OST level response to overall confidence in managing PCR with vitreous loss

\begin{tabular}{lllll}
\hline & $\begin{array}{l}\text { Would need } \\
\text { supervisor/nearby } \\
\text { senior to take over }\end{array}$ & $\begin{array}{l}\text { Could manage only with } \\
\text { senior assistance } \\
\text { (scrubbed at microscope) }\end{array}$ & $\begin{array}{l}\text { Could manage but with senior } \\
\text { assistance on stand-by (unscrubbed in } \\
\text { theatre/coffee room/office) }\end{array}$ & $\begin{array}{l}\text { Could complete } \\
\text { case without } \\
\text { senior support }\end{array}$ \\
\hline OST1 & $95.8 \%(23)$ & $4.1 \%(1)$ & $0(0)$ & $0(0)$ \\
OST2 & $46.4 \%(13)$ & $53.6 \%(15)$ & $0(0)$ & $0(0)$ \\
OST3 & $17.6 \%(6)$ & $58.8 \%(20)$ & $23.5 \%(8)$ & $0(0)$ \\
OST4 & $14.3 \%(6)$ & $47.6 \%(20)$ & $33.3 \%(14)$ & $4.8 \%(2)$ \\
OST5 & $8.2 \%(4)$ & $24.5 \%(12)$ & $53.1 \%(26)$ & $14.3 \%(7)$ \\
OST6 & $2.6 \%(1)$ & $10.5 \%(4)$ & $55.3 \%(21)$ & $31.6 \%(12)$ \\
OST7 & $0(0)$ & $0(0)$ & $28.1 \%(9)$ & $71.9 \%(23)$ \\
\hline
\end{tabular}


survey evaluating this issue exclusively with a series of directed questions at specific technical and non-technical principles, before responders self-evaluated themselves. It is usually anticipated that registrars from OST 4 onwards start to undertake independent cataract surgeries (either on their own/with a senior unscrubbed in theatre or within close vicinity). Subgroup analysis found only $14.3 \%$ at OST 4 and $38.8 \%$ at OST 5 levels rated themselves as confident enough in possessing the theoretical knowledge to independently manage PCR and vitreous loss. This increased to $60.5 \%$ of OST 6 and $90.6 \%$ of OST 7 responders. Reassuringly the majority of final year registrars exceeded the college requirement of a minimum of 350 phacoemulsification procedures and $71.9 \%$ of registrars at this level felt confident to manage vitreous loss without senior support. However a noticeable discrepancy was seen with confidence regarding fluidic parameters and anterior vitrectomy settings. Only $7.9 \%$ rated themselves as 'very confident' at OST 6 level. At OST 7 level, this stood at $37.5 \%$ being 'very confident' and $56.3 \%$ being 'quite confident' respectively. This survey therefore highlights a potential shortcoming in the current OST programme, particularly in registrars who will be progressing towards consultant level.

A number of solutions have been proposed to remedy this in recent years. OST curriculum delivery in the UK is regulated by the Royal College of Ophthalmologists (RCOphth). In 2015 the concept of mandatory simulation was introduced by the RCOphth into the OST curriculum. While wet-lab environments facilitating the use of enucleated animal [24] or model eyes [25] are well established, their effectiveness is limited by the lack of feedback or objective assessment when undertaken alone. This has led to high-fidelity virtual reality simulators gaining an increased prominence in ophthalmic training programmes. In 2010, the use of EyeSi ${ }^{\circledR}$ (VRmagic, Mannheim, Germany) was first introduced into UK training programmes and is continuing to gather evidence for its beneficial role in training. Studies have noted the ability of the EyeSi ${ }^{\circledR}$ to distinguish between novice, intermediate and advanced surgeon $[26,27]$ as well as to enable transference of skills acquired into the operating theatre [28]. Both these attributes allow for surgical training in a controlled environment. Ferris et al. conducted a UK multicentre study finding a 38\% reduction in unadjusted PCR rates for first and second year registrars between 2009 and 2015, aligned with the introduction of EyeSi ${ }^{\circledR}$ [29]. As of 2017, a new EyeSi ${ }^{\circledR}$ module dedicated to anterior vitrectomy has become widely available. Other recent college curriculum developments included the introduction of 'Entrustable Professional Activities' workplace-based assessments in 2016, where registrars must demonstrate the ability to manage an entire cataract theatre list independently. The concept of anterior vitrectomy mock exercises has also been shown to be potentially beneficial [30], where the importance of non-technical factors and prior preparation have been demonstrated.

Although this survey captured the highest response to date on this topic, it is prone to recall bias and reliant on registrars self-evaluating themselves. There were also regional variations in response rates and across all levels of OST. Nevertheless this survey offers a unique insight into current levels of expertise amongst UK registrars in managing this complication. Despite an evolving curriculum, our survey highlighted that only half of senior trainees (OST 6-7) were confident to manage PCR independently. Significant knowledge gaps surrounding fluidics and anterior vitrectomy settings were noted in all year groups.

\section{CONCLUSION}

We propose that a unifying assessment for PCR and vitreous loss management be developed and incorporated into the OST curriculum. This may be best achieved through using a simulator or simulating a PCR event, which takes account of the technical and non-technical factors at play. A standardised assessment delivered from a national platform will assist in producing more confident registrars for the future and ultimately enhance patient safety in cataract surgery. 


\section{ACKNOWLEDGEMENTS}

Funding. No funding or sponsorship was received for this study or publication of this article.

Authorship. All named authors meet the International Committee of Medical Journal Editors (ICMJE) criteria for authorship for this manuscript, take responsibility for the integrity of the work as a whole and have given final approval for the version to be published.

Author Contributions. All authors were involved in manuscript drafting and approval of final manuscript draft. Andrew J. Swampillai and Jonathan C. Park conceived the study concept and survey design. James E. Neffendorf assisted with statistical analysis. All authors were involved in manuscript drafting and approval of final manuscript draft. Victoria A. Nowak and Laura Maubon contributed as joint second authors. Collaborators: Sajjad Abbas, Yasmine Abdalla, Ahmed Abdel-Hay, Kavita Aggarwal, Eleftherios Agorogiannis, Kim L Wong Ah-See, Mahmoud Ahmed, Sohail Ahmed, Dana Ahnood, Engin Akyol, Alia Z. AlMousawi, Pouya Alaghband, Abid Ali, Komal Amir, Vivian Anakwenze, Martin Anderson, Roxanne Annoh, Abdus S Ansari, Chris Ashton, Michelle Attzs, John Awad, Mohamad Baba, Rinoza M Bafiq, Shafi Balal, Shiama Balendra, Alexander J Baneke, Kerolos Bassilious, Daniel Beck, Shahiba Begum, Tasmin Berman, Palvi Bhardwaj, Hetvi Bhatt, Robert Blizzard, Edward Bloch, Hannaa Bobat, Ramez Borbara, Neil Bowley, Helen Breen, Alice Bruynseels, David Burton, Emily Cabourne, Robert Cann, Edward J Casswell, Rupinder Chahal, Ritu Chaturvedi, Zhihang Cheng, Yu Jeat Chong, Munazzah R Chou, Ben Clarke, Neil Clough, Andrew Cowdray, Sophie Cowen, Nicola Cronbach, Ian De Silva, Elisabeth De Smit, Sundeep Deol, Jennifer Doyle, David Dunleavy, Rahul Dwivedi, Francis Edozie, Ahmad Elsahn, Abbas Fahem, Lana A Faraj, Bryher Francis, Lanxing Fu, William FusiRubiano, Kunal A Gadhvi, Weh Loong Gan, Anurag Garg, Matthew Gillam, Jeremy GilmourWhite, Vidushi Golash, Jack Gormley, Daniel B
Gosling, Chandni Gupta, Sam P Gurney, Zoya Hameed, Sana Hamid, Aaminah Haq, Joshua P Harvey, Juliana Helou, Mary Henry, William Hickman, Aisling Higham, Jennifer Hind, Derek Kwun-Hong Ho, Anindita Hom-Choudhury, Laura Hughes, Patrick Hughes, Samantha Hunt, Mohammed A Ismailjee, Daniel J Jackson, Mishank Jain, Zakariya Jarrar, Muhammed Jawad, Thomas Jenyon, Li Jiang, Fidan Jmor, Abigail Jonas, Varsha Kadaba, Sam Kanavati, Harikesh Kaneshayogan, Usama Kanj, Simerdip Kaur, Alasdair Kennedy, Marianne T Kennedy, Adnan Khan, Soyang Ella Kim, Varo Kirthi, Lyudmila Kishikova, Su-Yin Koay, Georgios Kontos, Adriana Kovacova, Jae Yee Ku, Mong-Loon Kuet, Muhammad Kutubi, Masara Laginaf, Mark Lane, Heidi Laviers, Duncan Leadbetter, Chan Ning Lee, Sarah Levy, Marcus Lim, Wei Sing Lim, Phey Feng Lo, Lin Lu, Sheila Luk, Ian JC Maccormick, Tejal Magan, Matthew Maguire, Mohsan Malik, Sunil Mamtora, Priyanka Mandal, Varshini Manoharan, Muhammed A Memon, Paul R Meredith, Sri V Merugumala, Luke Michaels, Neda Minakaran, Alexander Mitchell, Tariq Mohammad, Abhijit A Mohite, Robert Moreton, George Moussa, Fizza Mushtaq, Jayavani Myneni, Hasan Naveed, Eric K Newcott, Jonathan K Ng, Chandni Nigam, Linda Okafor, Arthur Okonkwo, Yuhan Ong, Jesse Panthagani, Esther Papamichael, Nicola Parker, Tina Parmar, Darshak S Patel, Mohsin Patel, Ajay Patil, Fraser Peck, Ricardo D Peixoto, Ioana Pereni, Joshua D Pilling, Ali Poostchi, Liam Price, Muhammed O Qadir, Madyan N Qureshi, Radhika Rampat, Sana Rasool, Ian Reekie, Ahmed Roble, Claire Routledge, Sohaib Rufai, Amun Sachdev, Emma Samia-Aly, Priyanka Sanghi, Edward Saxby, Matthew Schneiders, Christopher B Schulz, Paolo Scollo, Anastasios E Sepetis, Parth A Shah, Vishal Shah, Ahmed Shalaby, Mohith Shamdas, Bhavana Sharma, Thomas Sherman, Anthony Shinton, Mark Sigona, Peng Yong Sim, Chrishnepriya Sivapathasuntharam, Jan J Sniatecki, Emily Stedman, Paul Steptoe, Stephen Stewart, Niamh Stone, Stacey A Strong, Sara Syed, Kimberly Tan, Michelle Teo, Boon Lin The, Korina Theodoraki, Alice Thomas, Michelle Ting, Darren SJ Ting, Lauren Van Lancker, Pratibha Veeramani, Pratibha Veeramani, Jasvir Virdee, Panos 
Vouzounis, Lawrence Z Walker, Martin Wasik, James Wawrzynski, Sidath Wijetilleka, Caroline Wilde, Megan Wood, Ivan Yip, Imran H Yusuf, Camille Yvon.

Disclosures. Pravin J. Patel is a consultant for Novartis UK and Bayer UK and has received travel grants and research funding from Bayer UK. Andrew J. Swampillai, Victoria A. Nowak, Laura Maubon, James E. Neffendorf, Dilraj Sahota, Olayinka Williams, Bansri Lakhani, Cristina Soare, Ivan Sychev, Edward Ridyard and Jonathan C. Park have nothing to disclose.

Compliance with Ethics Guidelines. This article does not contain any new studies with human or animal subjects performed by any of the authors.

Data Availability. The datasets generated during and/or analysed during the current study are available from the corresponding author on reasonable request. The authors would like to thank the medical education faculty of Torbay Hospital for the use of their SurveyMonkey account, the training programme directors across the UK who supported the dissemination of this survey, as well as the survey respondents.

Open Access. This article is licensed under a Creative Commons Attribution-NonCommercial 4.0 International License, which permits any non-commercial use, sharing, adaptation, distribution and reproduction in any medium or format, as long as you give appropriate credit to the original author(s) and the source, provide a link to the Creative Commons licence, and indicate if changes were made. The images or other third party material in this article are included in the article's Creative Commons licence, unless indicated otherwise in a credit line to the material. If material is not included in the article's Creative Commons licence and your intended use is not permitted by statutory regulation or exceeds the permitted use, you will need to obtain permission directly from the copyright holder. To view a copy of this licence, visit http://creativecommons.org/licenses/bync/4.0/.

\section{REFERENCES}

1. Donachie J, Sparrow JM, Johnston RL. Year 1 annual report-piloting of the national ophthalmology database audit methodology national ophthalmology database audit. 2016. https://www. nodaudit.org.uk/u/docs/20/thsumcnchv/NOD\% 20Audit\%20Annual\%20Report\%202016.pdf. Accessed 2 Apr 2020.

2. The Royal College of Ophthalmologists 2010 Cataract surgery guidelines. London. https://www. rcophth.ac.uk/wp-content/uploads/2014/12/2010SCI-069-Cataract-Surgery-Guidelines-2010SEPTEMBER-2010.pdf. Accessed 2 Apr 2020.

3. Jaycock P, Johnston RL, Taylor H, et al. The Cataract National Dataset electronic multi-centre audit of 55,567 operations: updating benchmark standards of care in the United Kingdom and internationally. Eye (Lond). 2009;23(1):38-49.

4. Day AC, Donachie PH, Sparrow JM, Johnston RL, Royal College of Ophthalmologists' National Ophthalmology Database. The Royal College of Ophthalmologists' National Ophthalmology Database study of cataract surgery: report 1, visual outcomes and complications. Eye (Lond). 2015;29(4):552-60.

5. Ti SE, Yang YN, Lang SS, Chee SP. A 5-year audit of cataract surgery outcomes after posterior capsule rupture and risk factors affecting visual acuity. Am J Ophthalmol. 2014;157(1):180-185.e1.

6. Narendran N, Jaycock P, Johnston RL, et al. The Cataract National Dataset electronic multicentre audit of 55,567 operations: risk stratification for posterior capsule rupture and vitreous loss. Eye (Lond). 2009;23(1):31-7.

7. Royal College of Ophthalmologists-Award of the Certificate of Completion of Training (CCT). https://www.rcophth.ac.uk/training/certificationof-training-and-specialist-training/award-of-thecct/. Accessed 2 Apr 2020.

8. Johnston RL, Taylor H, Smith R, Sparrow JM. The Cataract National Dataset electronic multi-centre audit of 55,567 operations: variation in posterior capsule rupture rates between surgeons. Eye (Lond). 2010;24(5):888-93.

9. Turnbull AM, Lash SC. Confidence of ophthalmology specialist trainees in the management of posterior capsule rupture and vitreous loss. Eye (Lond). 2016;30(7):943-8.

10. Health Research Authority. Is my study research? http://www.hra-decisiontools.org.uk/research/. Accessed 10 Jan 2020. 
11. Hanumunthadu D, Nowak VA, Hassan F, et al. Treatment delivery for patients with neovascular AMD in the UK: results from an Ophthalmology Trainee Clinical Research Network Study. Ophthalmol Ther. 2017;6(2):295-300.

12. Abdelfattah NS, Radwan AE, Sadda SR. Perspective of ophthalmology residents in the United States about residency programs and competency in relation to the International Council of Ophthalmology guidelines. J Curr Ophthalmol. 2016;28(3): 146-51.

13. Zhou AW, Noble J, Lam WC. Canadian ophthalmology residency training: an evaluation of resident satisfaction and comparison with international standards. Can J Ophthalmol. $2009 ; 44(5): 540-7$.

14. Dean W, Gichuhi S, Buchan J, et al. Survey of ophthalmologists-in-training in Eastern, Central and Southern Africa: a regional focus on ophthalmic surgical education. Wellcome Open Res. 2019;4:187.

15. Dean WH, Grant S, McHugh J, Bowes O, Spencer F. Ophthalmology specialist trainee survey in the United Kingdom. Eye (Lond). 2019;33(6):917-24.

16. Ellis EM, Lee JE, Saunders L, Haw WW, Granet DB, Heichel CW. Complication rates of resident-performed cataract surgery: Impact of early introduction of cataract surgery training. J Cataract Refract Surg. 2018;44(9):1109-15.

17. Sadideen H, Kneebone R. Practical skills teaching in contemporary surgical education: how can educational theory be applied to promote effective learning? Am J Surg. 2012;204(3):396-401.

18. Rodrigues IA, Symes RJ, Turner S, Sinha A, Bowler G, Chan WH. Ophthalmic surgical training following modernising medical careers: regional variation in experience across the UK. BMJ Open. 2013;3(5):e002578.

19. Guly C, Sidebottom R, Hakin K, Bates K. Challenges of private provision in the NHS: treatment centres and their effect on surgical training. BMJ. 2005;331(7528):1338.

20. Au L, Saha K, Fernando B, Ataullah S, Spencer F. "Fast-track" cataract services and diagnostic and treatment centre: impact on surgical training. Eye (Lond). 2008;22(1):55-9.

21. Grandinetti A, Suenaga D, Oliveira FM, Cruz KS, Meneguette L, Moreira LB. Results of pars plana vitrectomy after complicated phacoemulsification surgery. Arq Bras Oftalmol. 2015;78(2):73-5.

22. Jamison A, Benjamin L, Lockington D. Quantifying the real-world cost saving from using surgical adjuncts to prevent complications during cataract surgery. Eye (Lond). 2018;32(9):1530-6.

23. Ali N, Little BC. Causes of cataract surgery malpractice claims in England 1995-2008. Br J Ophthalmol. 2011;95(4):490-2.

24. van Vreeswijk H, Pameyer JH. Inducing cataract in postmortem pig eyes for cataract surgery training purposes. J Cataract Refract Surg. 1998;24(1):17-8.

25. Maloney WF, Hall D, Parkinson DB. Synthetic cataract teaching system for phacoemulsification. J Cataract Refract Surg. 1988;14(2):218-21.

26. Spiteri AV, Aggarwal R, Kersey TL, et al. Development of a virtual reality training curriculum for phacoemulsification surgery. Eye (Lond). 2014;28(1):78-84.

27. Mahr MA, Hodge DO. Construct validity of anterior segment anti-tremor and forceps surgical simulator training modules: attending versus resident surgeon performance. J Cataract Refract Surg. 2008;34(6):980-5.

28. McCannel CA, Reed DC, Goldman DR. Ophthalmic surgery simulator training improves resident performance of capsulorhexis in the operating room. Ophthalmology. 2013;120(12):2456-61.

29. Ferris JD, Donachie PH, Johnston RL, Barnes B, Olaitan M, Sparrow JM. Royal College of Ophthalmologists' National Ophthalmology Database study of cataract surgery: report 6. The impact of EyeSi virtual reality training on complications rates of cataract surgery performed by first and second year trainees. Br J Ophthalmol. 2020;104(3):324-9.

30. Lockington D, Belin M, McGhee CNJ. The need for all cataract surgeons to run a regular vitreous loss fire drill. Eye (Lond). 2017;31(8):1120-1. 